\title{
Industry segment effects and firm effects on firm performance in single industry firms
}

\author{
Noël Houthoofd
} Jef Hendrickx

HUB RESEARCH PAPERS 2012/17

ECONOMICS \& MANAGEMENT

MAART 2012



\section{Industry segment effects and firm effects on firm performance in single industry firms}

Noël Houthoofd, HUBrussel, Department of Economics and Management

noel.houthoofd@hubrussel.be

Jef Hendrickx, HUBrussel, Department of Economics and Management

jef.hendrickx@hubrussel.be 


\begin{abstract}
The purpose of the paper is to identify the sources of variation in firm performance. This is one of the cornerstones of strategy research, i.e. the relative importance of industry and firm level effects on firm performance. Multilevel analysis is well suited to analyze variance in performance when the data are hierarchically structured (industry segments consist of firms, firms operate within the context of industry segments). The Belgian industry studied is a service industry that consists of about 25 electrical wholesalers. Data were collected from 20 firms during the period 1998-2003 from responses to a questionnaire sent to all the firms in the market. The sample in the data set covers more than 95 percent of the market (in sales), as the missing firms were just fringe competitors. The results show that firm effects explain most of the variance in four performance variables. That bears out the importance of each firm having its own specific, idiosyncratic resources and competences. The explanatory power of firm effects varies by about 30 to 40 percent while the intra-industry effect explains around 10 percent of the variance. Even though firm effects are dominant, intra-industry effects explain a significant portion of the variance in firm level performance. The firm effect is smaller than in previous studies. The firm effect varies across the performance measures: firm effects are higher for returns on assets than for profit margins. The industry segment effect (or intra-industry effect) is more independent of the dependent variable. The industry segment effect is in line with previous studies on the strategic group effect. Top managers should carefully choose and monitor the intra-industry domain they are in.
\end{abstract}

Key words: firm effect vs. industry effect, electrical wholesale sector, performance differences, multilevel analysis 


\section{Introduction}

Identifying the sources of variation in firm performance is one of the cornerstones of strategy research, i.e. the relative importance of year, country, industry, strategic group, corporate, and firm level effects. The literature focuses on comparing the relative importance of industry and firm effects on performance heterogeneity. The confrontation of these two effects is then interpreted as an empirical test of the practical relevance of the two fundamental research streams that aim to explain differences in firm performance: perspectives that highlight firm characteristics as the key determinant of firm performance - e.g. the resource based view (RBV) (Wernerfelt, 1984; Barney, 1986, 1991), the competence-based view (CBV) (Sanchez, 1997; Sanchez \& Heene, 1997) or the dynamic capabilities view (DCV) (Teece, Pisano and Shuen, 1997; Teece, 2010), and perspectives that emphasize the impact of the environment - e.g. industrial organization (IO) (Porter, 1979, 1980, 1981) and population ecology theory (Hannan and Freeman; Nelson and Winter, 1982).

This paper starts with a conceptualization of the different effects studied in previous research and positions the industry segment effect amidst the other effects studied in this research stream. A third section provides a review of past studies on the topic of the relative importance of the different drivers of firm performance. A fourth section presents the research setting. The fifth section discusses the research method. Section six presents and discusses the results.

\section{Explaining heterogeneity in firm performance - theoretical background}

\subsection{Firm effects and industry effects}

The main focus of interest in the literature on explaining performance differentials is the industry versus the firm effect. The continuing debate in the literature about the relative weight of the industry versus the firm (or business unit) reflects a debate between the importance of looking through the window (the industry or market) vs. looking in the mirror (the company itself) (Bowman and Helfat, 2001)

The industry effect captures the effect of the structural characteristics of industries on firm performance. This effect has strong theoretical foundations in the IO tradition. The IO approach, emerging from the early works of Mason (1939) and Bain (1951, 1956), specifies that the contextual factors associated with the industry in which a firm competes, have a determining influence on the firm's performance. This approach places little emphasis on the influence of firm-specific traits or managerial choices (with the exception of market share). In IO, firms are mostly homogeneous while contexts (industries) differ (e.g. in structure, timing, costs, demand, etc). The IO view explains firm performance differences through the relative attractiveness of forces in a firm's industry (Porter, 1979, 1980, 1981). According to the IO-view, the industry 
affects firm performance independently of the firm itself (Arend, 2009). Industry-level determinants studied consist of concentration, economies of scale, entry and exit barriers.

The IO framework was challenged in the 1980s by the incipient RBV, which modeled the firm as a unique collection of resources and competences which forms the main driver of firm performance. Firm effects capture the influence of firm-specific factors such as heterogeneity in resources and competences and also the differences in corporate and competitive strategies. According to the RBV, internal firm-specific factors are of central concern because these internal factors drive performance, not external industry forces (Barney, 1991). Wernerfelt (1984:172) defines a resource as "anything which could be thought of as a strength or a weakness". In more recent work, a distinction is made between a wide variety of tangible and intangible assets and competences (Hall, 1994; Hunt, 2000). Scholars in the RBV literature theorize that firms possessing resources that are valuable, rare, inimitable, and nonsubstitutable can achieve sustainable competitive advantage by implementing fresh value-creating strategies that are difficult for competitors to duplicate (Barney, 2002; Wu, 2010). Examples include intellectual property, process know-how, customer relationships, and the knowledge possessed by groups of especially skilled employees. Within RBV, competitive advantage can flow at one particular moment from ownership of scarce but relevant and difficult-to-imitate assets, especially knowhow. But in fast-moving business environments open to global competition, sustainable advantage requires more than the ownership of difficult-to-replicate (knowledge) assets (Teece, 2007). Scholars of the CBV and the DCV are extending RBV to dynamic markets. The CBV and DCV can be seen as more actionable versions of the RBV, with more emphasis on the sources of competitive advantage in the firm over time. The CBV shifts the focus from the specific content of the firm as an open system at a given point in time to the dynamic processes by which a firm identifies and develops strategic resources on an ongoing basis (Sanchez, 1997). Thus the competence perspective analyzes processes in organizations in terms of making sense in a changing environment, for developing new internal resources and capabilities, for accessing new external resources, for defining new organizational goals, and for coordinating available resources and capabilities in the pursuit of an evolving set of strategic goals. As such there is a strong link with organizational learning theory. The dynamic capabilities are the skills, procedures, organizational structures, and decision rules that firms utilize to create and capture value (Teece, 2010). Dynamic capabilities can be disaggregated into the capacity (1) to sense and shape opportunities and threats, (2) to seize opportunities, and (3) to maintain competitiveness through enhancing, combining, protecting, and, when necessary, reconfiguring the enterprise's intangible and tangible assets (Teece, 2007). Though DCV emphasizes more organizational agility, cognition and entrepreneurship whereas CBM calls attention to strategic flexibility, the CBV and the DCV frameworks are complementary. 


\subsection{Incorporating intra-industry effects}

The persistent observation of shared similarities in the endowment of resources among (strategic) groups of firms in the same industry reinforced the need to consider intra-industry effects which affect subgroups of firms within the industry. Firm effects would be overestimated if intraindustry differences and similarities were not accounted for. The existence of significant intraindustry effects may stimulate practicing managers to align the firm's corporate strategy within the industry context. Unfortunately, only a few studies have taken into account these intraindustry effects of firm heterogeneity on performance variation. According to Hawawini, Subramanian, and Verdin (2003), industry effects and firm effects may vary between different classes of firms within the same industry - for example, if the industry is made up of distinct strategic groups. This argument is generalizable to form the hypothesis that industry effects and firm effects may vary if different intra-industry segments exist. If this is the case, then it follows that in a single industry research design, firm effects will be lower than estimates in previous studies, because these studies decompose performance variation between firms without taking intra-industry effects into account. Even when industry is defined at the four digit level, a large variation in firm level performance is usually found, as is the case in this paper. Trying to explain these large variations calls for consideration of intra-industry structural differences which can give rise to an "industry segment effect" or "intra-industry effect", and this in turn may reduce significantly the influence of firm effects on performance.

The existence of industry segments may trigger practicing managers to align their corporate strategy with this intra-industry context. Even when CEOs face the same general external environment (e.g. the industry), they will react differently to the threats and opportunities perceived within that context. This study is one of the few addressing the performance differentials which can be attributed to an industry segment effect. This is correlated with the effect of corporate level scale and scope decisions but must not be confused with the 'corporate effect' as this is usually conceptualized. The notion of corporate effect means the effect on profitability in multi-industry firms in relation to factors associated with the common membership of multiple businesses within an individual corporation (Bowman and Helfat, 2001). Corporate strategy in a multi-industry firm deals with the ways in which a corporation manages a set of businesses as a whole. Firms differ in the way they deploy corporate-level resources and this is likely to result in performance heterogeneity across firms. In single industry firms, corporate level decisions comprise three different strategic areas, which, together, define the intra-industry segment or intra-industry domain which the firm operates in. These three basic dimensions are (Cool and Schendel, 1987, 1988; Porter, 1986; Martens, 1988, 1989; McGee and Segal-Horn, 1990):

- Buyer scope: what types of buyers are targeted?

- Product scope: how broad is the variety of products commercialized?

- Geographical scope: what is our geographical reach? 
Industry segment effects would capture the heterogeneity of firm performance that derives from factors internal to the firm at the corporate level (e.g. scale and scope decisions, (re)structuring the organization) (Adner and Helfat, 2003). This paper focuses primarily on scale and scope decisions. Hence the following research question: do corporate level decisions differ across firms within an industry, and, if so, does it matter? In this study, the industry effect is let aside because the present sample considers a single industry, the electrical wholesale sector. The intra-industry domain is a three-dimensional (cf. infra) "strategic space" constituting the arena within which firms position themselves in order to compete successfully. Variation in any of these three dimensions significantly affects a firm's structural position in the industry. We hypothesize that the variation has relevant performance implications. We use multilevel analysis to answer the question of whether heterogeneity in corporate level decisions accounts for a portion of heterogeneity in performance.

\section{Empirical literature review}

Since the seminal empirical research of Schmalensee (1985) more than 25 studies have contributed to the assessment of the relative importance of various different drivers of heterogeneity in firm performance. Table 1 summarizes the research setting and the main results of the most influential papers published in the academic literature. This list is based on, and extends, the reviews by Bowman and Helfat (2001); Brush, Bromiley, and Hendrickx (1999); Chen and Lin (2006); Misangyi, Helms, Greckhamer, and Lepine (2006) and Arend (2009). Most of the studies are based on US data and just a few of them analyze information concerning European firms. The recent contribution of Goddard, Tavakoli, and Wilson (2009) uses European data from the Amadeus database. This paper adds to previous literature through an analysis of a country effect that is considered together with firm and industry effects. Almost all the papers reported in the Appendix rely on published financial performance data. Only Powell (1996) and, more recently, Galbreath and Galvin (2008) use subjective performance data with US and Australian data respectively.

The great majority of the studies focus on the relative importance of industry (market) versus firm (resources) characteristics, adjusting for time effects. Industry effects vary from 4 to 20 percent when indicators of financial performance are used as dependent variables. The two studies that use subjective measures of perceived performance also report industry effects around the same range of values, which suggests that reported and perceived performance measures contain similar information. By way of contrast, when indicators of strategic decisions are the dependent variables (Mauri and Michaels, 1998), the industry effects rise to 69 percent. Using sales or sales growth also leads to large industry effects. Two studies use Tobin's q as the dependent variable with industry effects varying from 20 to 41 percent. To sum up, most studies found firm effects to be dominant. The relative importance of firm effects ranges from twice the importance of industry effects (Hansen and Wernerfelt, 1989) to more than ten times (Rumelt, 
1991). In the ongoing debate about the drivers of firm performance heterogeneity, these results are often interpreted as evidence in favor of RBV, CBV or DCV arguments (Galbreath and Galvin, 2008).

However, firm and industry effects are not the only drivers of heterogeneity in firm performance. Corporate effects have been estimated in ten studies and the results suggest an explanatory power for this effect that ranges from 3 to 13 percent. Sample selection can explain some of the wide differences in the assessment of corporate effects. The results of studies of the corporate effect which excluded single industry firms from the sample differ from those which included both diversified and single industry firms. In addition, the effects of intra-industry variety on firm performance remain largely unexplored. González and Ventura (2002) were the first to jointly estimate a strategic group effect together with firm and industry effects in a sample of Spanish firms. Their estimation of the strategic group effect ranges from 11 to 15 percent. These results are consistent with the estimations in Short, Ketchen, Palmer, and Hult (2007) which range from 12 to 24 percent. Adner and Helfat (2003) analyze the effect of intra-industry segments, estimating an explanatory power of 6 percent. Finally, interaction effects have also been taken into account in some of the studies, although their incidence was found to be rather small (Eriksen and Knudsen, 2003).

The paper here does not aim to contribute to the debate about the relative importance of firm versus industry effects. Instead, the focus is on the debate about intra-industry effects. The study focuses on a single industry sample, which makes it unnecessary to control for industry effects. This is the second single industry study on the topic of decomposing firm performance variance, Adner and Helfat (2003) being the first. Another notable difference from previous studies is that this study analyzes a services sector, the Belgian electrical wholesale sector. Almost all the papers in Table 1 use data from manufacturing firms and most of them focus on US firms. The data for the present study come from a survey designed to collect objective financial performance data at the business unit (firm) level and also information about corporate strategy. The study estimates intra-industry effects and compares them with firm effects in a single industry dataset using information about different measures of performance and variables of corporate strategy.

\section{Empirical setting}

The single-industry setting of this empirical research facilitates testing the proposition that heterogeneity in the managerial decisions adopted at the corporate level is associated with heterogeneity in firm performance. The Belgian industry studied is a service industry that consists of about 25 electrical wholesalers and the research conducted was actively supported by the union of electrical wholesalers. Data were collected from 20 firms during the period 1998-2003 from responses to a questionnaire sent to all the firms in the market. The sample in the data set covers more than 95 percent of the market (in sales), as the missing firms were just fringe competitors. All the firms in the data set are family-owned private firms, with sales varying from EUR 4 million 
(25th percentile) to more than EUR 28 million (75th percentile) with a median of EUR 8 million. Employment figures range from 14 (25th percentile) to 78 (75th percentile) with a median of 28 employees (see Table 1).

Table 1: some descriptives of the Belgian electrical wholesale sector

\begin{tabular}{rccc} 
& \multicolumn{3}{c}{ Percentiles } \\
& 25 & 50 & 75 \\
Employment (in units) & 14 & 28 & 78 \\
Total net profits (in EUR) & 2735.95 & $130,024.58$ & $348,797.43$ \\
Total Assets (in EUR) & 2159754.25 & 4236412.91 & 10646924.00 \\
Inventories (in EUR) & 657604.72 & 1062911.75 & 2422405.29 \\
Sales (in EUR) & 4537066.16 & 8737122.75 & 28753382.00
\end{tabular}

The questionnaire was carefully prepared with the participation of members of the wholesalers' union, who also did the mailing in order to assure a high response rate. Questionnaires were returned directly to the first author, guaranteeing full discretion concerning the data provided, which in turn helped boost the response rate. Great attention was paid to the correct wording of the questions and to the comprehensiveness of the questionnaire. The response rate was high due to the active support of the wholesalers' union. The wholesalers are well aware of the potential threats posed to their sector and this increases their interest in the results of this research project. Manufacturers of electrical material have the potential to sell directly to business clients and installers and, therefore, the wholesalers might get squeezed between producers and final customers and retailers. To create value in the industry chain and neutralize these threats, the largest wholesalers have built various warehouses that are located across the territory. Some wholesalers also try to stress distinctive features by specializing in a specific combination of products aimed at specific segments of the market.

\section{Methods}

\subsection{Measures used in this study}

Survey data were collected on the scale and scope strategic dimensions of single industry firms. In particular, three decision variables were considered. Performance is measured with four variables. An overview of the measures used and their modus operandi can be found in Table 2 and some descriptive statistics of the sample in Table 3. 
Table 2: Operationalization of variables

Corporate Strategy Variables

Market scope (buyer types)

Product scope (product types)

Geographical reach

\section{Performance Variables}

Gross return on business assets (gROBA)

Net return on business assets (nROBA)

Gross profit margin (gPM)

Net profit margin (nPM)

\section{Operational definition}

$\%$ sales business clients

$\%$ sales electricians (installers)

$\%$ sales installation material

$\%$ sales lighting material

size [log (sales)]

\section{Operational definition}

Gross operating profit per business assets

Net operating profit per business assets

Gross operating profit per sales

Net operating profit per sales

Table 3: descriptive statistics of the sample on the corporate strategy variables: rank correlations, minimum, maximum and quartiles

\begin{tabular}{|c|c|c|c|c|c|c|}
\hline \multicolumn{2}{|l|}{ Rank correlations } & $(\mathrm{A})$ & \multicolumn{2}{|c|}{ (B) } & (C) & (D) \\
\hline \multicolumn{2}{|c|}{$\%$ sales to business clients $(\mathrm{A})$} & 1.00 & & & & \\
\hline \multicolumn{2}{|c|}{$\%$ sales to electricians $(\mathrm{B})$} & -.77 & \multicolumn{2}{|c|}{1.00} & & \\
\hline \multicolumn{2}{|c|}{$\%$ sales of installation material $(\mathrm{C})$} & .52 & \multicolumn{2}{|c|}{-.46} & 1.00 & \\
\hline \multicolumn{2}{|c|}{$\%$ sales of lighting material (D) } & -.40 & \multicolumn{2}{|c|}{.20} & -.43 & 1.00 \\
\hline \multicolumn{2}{|r|}{ size $(E)$} & -.16 & \multicolumn{2}{|c|}{.30} & -.11 & -.21 \\
\hline \multicolumn{2}{|l|}{ Minimum, maximum and } & \multicolumn{5}{|c|}{ Percentiles } \\
\hline quartiles & $N$ & Min & $25 t h$ & $\begin{array}{c}\text { (Median) } \\
\text { 50th }\end{array}$ & $75 t h$ & $\operatorname{Max}$ \\
\hline$\%$ sales to business clients & 20 & 5 & 18.88 & 25.23 & 35.75 & 69 \\
\hline$\%$ sales to electricians & 20 & 19 & 45.00 & 57.00 & 65.00 & 95 \\
\hline$\%$ sales of installation material & 20 & 35 & 42.18 & 53.43 & 59.74 & 73 \\
\hline$\%$ sales of lighting material & 20 & 8 & 18.62 & 21.75 & 25.66 & 44 \\
\hline Size & 20 & 5.26 & 5.88 & 6.16 & 6.60 & 7.39 \\
\hline
\end{tabular}

Scale and scope variables The competitive arena in which a firm operates can be defined by three dimensions: buyer scope, product scope, and geographical scope. Buyer scope is operationalized using two measures: percentage of sales to business clients and percentage of sales to electricians. Product scope is measured through two measures: the percentage of sales of lighting material and the percentage 
of sales of installation material. Geographical reach is measured using the proxy firm size and operationalized as the log of sales (Martens 1988, 1989; Houthoofd, Desmidt \& Gonzalez, 2009; Houthoofd, 2011).

Performance Measurement Performance is measured in terms of gross return on business assets (gROBA), net return on business assets (nROBA), gross profit margin (gPM), and net profit margin (nPM). A commonly used profitability measure is return on assets (ROA). Here, the focus is on the intrinsic profitability (or intrinsic health) of operating activities (in a broad sense, but to exclude purely financial or exceptional activities), and thus the ROBA is preferred. ROBA is also computed in such a way as to avoid the potential influence of participations in other firms. Business assets are non-financial assets (used here as an accounting term) and are composed of formation expenses, intangible assets, tangible assets, stocks and contracts in progress, amounts receivable within one year and deferred charges and accrued income. The larger this measure, the healthier the firm concerned is supposed to be. ROBA is a performance measure calculated before taxes and debt charges, so tax policy considerations and potential differences in tax rates are excluded. ROBA is computed (1) before debt charges to cope with differences in capital structure, (2) before depreciation charges (gROBA) and (3) after depreciation charges (nROBA). The profit margin is the ratio of operating profits to sales and is also calculated before (gPM) and after depreciation charges (nPM).

\subsection{Measurement of different effects on firm performance}

Two main statistical techniques are used to estimate the relative importance of different drivers of firm performance heterogeneity, such as firm, industry or intra-industry effects (Goddard, Tavakoli, and Wilson, 2009): (1) sequential (or nested) analysis of variance, also called fixed effects ANOVA, which is equivalent to a series of least square dummy variables regressions (LSDV); and (2) variance components analysis (VCA), also known as random effects ANOVA.

Nested ANOVA needs no prior assumption about the distribution of the fixed effects. In (nested) fixed effects models, interaction effects cannot be measured (see for example Hawawini et al., 2003). A fixed effects model is often chosen because it allows for distribution-free effects, nonnegative effects, and a statistical test for the significance of each set of effects. However, the nested effects have to enter in precise order from top (industry) to bottom (firm).

VCA assumes that the effects are randomly drawn from a theoretical population with a specific distribution. In VCA, the ordering of the random effects is unimportant because the underlying assumption is that each set of effects is independent. Therefore, all the effects can be estimated at once even if they are nested. However, Brush and Bromiley (1997) show that different samples drawn from the same underlying distribution of effects end up with very different estimates. They also point to the fact that for accurate estimation of the different effects adjustment for the number of industries, the number of corporations per industry and the number of businesses per corporation are all required for each sample of data. But in our study, a random effects model 
would make little theoretical sense, since the present sample nearly matches the whole population of firms in the industry. The limitations of the main methods used to estimate the different effects on performance lead us to the use of multilevel estimation. Hough (2006) and Misangyi et al. (2006) sum up the advantages of multilevel methods over traditional methods, like nested ANOVA or VCA. Analysis of the kind reported here should simultaneously take account of all the relevant scales of variation, otherwise models are wrongly specified with consequent errors of inference. Certainly there are interaction effects to deal with (e.g. a business of high performing firms may affect an individual firm's performance in addition to - and in interaction with - the firm's own characteristics). Businesses (or groups of firms) are rarely formed at random but rather on the basis of some similarity. Once established, the group members (firms within the same business) may interact with each other - deliberately or covertly or not - to create even greater similarity, and thus respondents within the same business are more likely to have similar characteristics than a sample drawn from the entire population at random. Working at a single level is likely to lead to a distorted representation of reality.

\subsection{Multilevel estimation}

Multilevel methods use the natural structure in the data. Firstly, the following random intercepts null model, with only a constant term, is estimated.

$$
\begin{aligned}
Y_{i t}=\alpha_{i}+e_{i t} & \\
& \text { whereby } \\
& e_{i t} \sim \mathrm{N}\left(0, \sigma_{\mathrm{e}}^{2}\right) \\
& Y_{i t} \text { is the performance of firm } i \text { in year } t \\
& e_{i t}=\text { year specific error } \\
& \alpha_{i}=\text { random intercept } \\
& \sigma_{\mathrm{e}}^{2}=\text { variance within a firm } \\
& \\
\alpha+ & u_{i}, \\
& \text { whereby } \\
& u_{i} \sim \mathrm{N}\left(0, \sigma_{\mathrm{e}}^{2}\right) \\
& \alpha=\text { general intercept } \\
& u_{i}=\text { firm specific error } \\
& \sigma_{\mathrm{e}}^{2}=\text { variance between firms }
\end{aligned}
$$

The parameter $\alpha_{i}$ is the random intercept and can be seen as the mean performance of firm $i$ across the years. In the second equation, this random intercept is written as the sum of the grand mean $\alpha$, which is the mean performance across all years and all firms, and a firm specific error $u_{i}$, which expresses how much the mean performance of firm $i$ deviates from the overall mean. We 
assume that the $u_{i}$ is normally distributed with a mean of 0 and a variance of $\sigma_{\mathrm{u}}^{2}$, so this variance expresses the between-firm variance. The time specific error term $e_{i t}$ expresses how much the performance of firm $i$ in year $t$ deviates from the mean performance of that firm across the years. The model assumes that $e_{i t}$ is distributed normally with a mean of 0 and a variance of $\sigma_{\mathrm{e}}^{2}$, and is independent of $u_{i}$. So $\sigma_{\mathrm{e}}^{2}$ can be interpreted as the variance within the firms across time. This null model is used to estimate the total variance in the data and to calculate how much of this variance is due to variance between firms and within firms.

Secondly, year dummys are added to the model (Year 1 is the reference category):

$$
\begin{aligned}
& Y_{i t}=\alpha_{i}+\beta_{1} \text { Year }_{\mathrm{i}}+\beta_{2} \text { Year }_{\mathrm{i}}+\beta_{3} \text { Year }_{\mathrm{i}}+\beta_{4} \text { Year5 } 5_{\mathrm{i}}+\beta_{5} \text { Year }_{\mathrm{i}}+e_{i t}, \\
& \text { whereby } \\
& \qquad e_{i t}=\text { year specific error } \\
& \alpha_{i}=\alpha+u_{i} . \\
& \text { whereby } \\
& u_{i}=\text { firm specific error }
\end{aligned}
$$

This will make it possible to see how much of the total variance can be eliminated by the year effects.

Finally, a segment dummy is added to the model, since each firm belongs to one of two segments, as will be explained later.

$$
\begin{aligned}
& Y_{i t}=\alpha_{i}+\beta_{1} \text { Year }_{\mathrm{i}}+\beta_{2} \text { Year }_{\mathrm{i}}+\beta_{3} \text { Year }_{\mathrm{i}}+\beta_{4} \text { Year }_{\mathrm{i}}+\beta_{5} \text { Year6 }_{\mathrm{i}}+\beta_{6} \text { Segment }_{\mathrm{i}}+e_{i t}, \\
& \alpha_{i}=\alpha+u_{i} . \\
& \quad \text { whereby } \\
& e_{i t}=\text { year specific error } \\
& u_{i}=\text { firm specific error }
\end{aligned}
$$

As already stated, this will make it possible to calculate how much of the total variance can be removed by adding the segment dummy to the model. 


\section{Research results}

\subsection{Delineating intra-industry domains}

The first part of the research question, "Do corporate level decisions differ across firms, and, if so, does it matter?" is answered by testing the existence of separate intra-industry segments given the business positioning of the different firms within the industry according to their corporate level strategic decisions. Cluster analysis (CA) is the most widely-used technique for investigating whether different domains are present within a single industry defined at four-digit level. But cluster analysis can be distorted by multicollinearity. For instance, as market scope and product scope are measured as a percentage of sales, the variables themselves are anyhow not independent. Therefore, a factor analysis, in particular a principal components analysis with orthogonal varimax rotation, was carried out beforehand on the corporate strategy variables. This preliminary step reduces the number of variables to a manageable and intelligible number of factors, which will be uncorrelated and therefore removes the problem of multicollinearity. Using the stopping rule that the eigenvalue exceeds 1, the factor analysis showed a 2-factor solution which Table 4 illustrates. The two factors can be identified as 'Product-Market-combination' (factor 1) and 'Scale' (factor 2); see Table 5.

Table 4: Factor analysis of the corporate strategy variables: eigenvalues and values explained

\begin{tabular}{|c|c|c|c|c|c|c|}
\hline \multirow[b]{2}{*}{ Component } & \multicolumn{3}{|c|}{ Initial Eigenvalues } & \multicolumn{3}{|c|}{ Rotation Sums of Squared Loadings } \\
\hline & Total & $\begin{array}{c}\% \text { of } \\
\text { Variance }\end{array}$ & $\begin{array}{c}\text { Cumulative } \\
\%\end{array}$ & Total & $\begin{array}{c}\% \text { of } \\
\text { Variance }\end{array}$ & Cumulative $\%$ \\
\hline 1 & 2.453 & 49.07 & 49.07 & 2.45 & 49.06 & 49.06 \\
\hline 2 & 1.257 & 25.15 & 74.21 & 1.26 & 25.15 & 74.21 \\
\hline 3 & .614 & 12.28 & 86.49 & & & \\
\hline 4 & .472 & 9.44 & 95.93 & & & \\
\hline 5 & .204 & 4.07 & 100 & & & \\
\hline
\end{tabular}


Table 5: Factor matrix of the business definition variables.

$\begin{array}{rcc} & \begin{array}{c}\text { Factor 1 } \\ \text { Product market } \\ \text { combination }\end{array} & \begin{array}{c}\text { Factor 2 } \\ \text { scale }\end{array} \\ \text { \% sales to business clients } & .89 & \\ \% \text { sales to electricians } & & .30 \\ \% \text { sales of installation material } & .77 & .84 \\ \text { size } & & -.66\end{array}$

Notes: 1. Data shown are factor loadings greater than or equal to 0.3

2. The matrix is sorted

3. Blanks for loadings smaller than 0.3 to enhance readability

Once the factor scores were computed and stored in the database, hierarchical CA (Ward's method) was performed on them in order to group firms into intra-industry segments. The results of the cluster analysis suggest that two different business domains (clusters) within the industry can be distinguished. The number of clusters was based on a visual inspection of the dendrogram and the pronounced change in the tightness of the clusters as measured by a sharp increase in the error sum of squares (ESS) between two fusions in a hierarchical CA method (Everitt, 1974). The KruskalWallis test confirms that the two clusters obtained are statistically different at the 0.05 significance level for both factors and also for all the original raw measures, except for the \% sales of lighting material (Table 6). Twelve firms operate within the first domain and eight firms in the second domain.

Table 6: Kruskal-Wallis test on the corporate strategy variables and factors: chi-square statistics

$\begin{array}{rccc} & \text { Chi- } & \text { df } & \text { Asymp. } \\ & \text { Square } & & \text { Sig. } \\ \% \text { sales to business clients } & 6.50 & 1 & .011 \\ \% \text { sales to electricians } & 13.46 & 1 & .000 \\ \% \text { sales of installation material } & 7.51 & 1 & .006 \\ \% \text { sales of lighting material } & .25 & 1 & .616 \\ \text { Size } & 4.34 & 1 & .037 \\ \text { Factor 1 product-market-combination } & 9.52 & 1 & .002 \\ \text { Factor 2 scale } & 6.10 & 1 & .014\end{array}$

The two clusters can be described as follows. Cluster 1: relatively small-sized firms mostly selling to business clients, low level of sales to electricians, above average sales of installation material and lighting material. Cluster 2: relatively large firms with low level of sales to business 
clients, high sales to electricians, below average sales of installation material and lighting material.

Firms in cluster 1 constitute industry segment 1 and firms in cluster 2 constitute industry segment two. The question now is whether these two segments differ from each other in average performance and whether those differences are large or small when compared to the differences that may also exist within the segments. Table 7 indicates that indeed these two clusters of firms are statistically different, at conventional significance levels, for each of the four performance measures. Observe Table 8 that cluster 1 is more profitable according to any of the four measures. The median of net profit margin in cluster 1 is 1.3 percent higher, gross profit margin is 1.6 percent higher, net ROBA is 3.6 percent higher, and gross ROBA is 5.5 percent higher relative to cluster 2 . At first sight this supports the idea that corporate strategy decisions matter and are an important driver of firm performance. The question then is, how important?

Table 7: Kruskal-Wallis test on the performance measures: chi-square statistics

$\begin{array}{rccc} & \begin{array}{c}\text { Chi- } \\ \text { Square }\end{array} & \text { df } & \begin{array}{c}\text { Asymp. } \\ \text { Sig. }\end{array} \\ \text { average nROBA } & 3.43 & 1 & .064 \\ \text { average gROBA } & 5.01 & 1 & .025 \\ \text { average nPM } & 2.88 & 1 & .090 \\ \text { average gPM } & 3.43 & 1 & .064\end{array}$

Table 8: intra-industry domains: descriptive statistics of performance measures per domain

\begin{tabular}{cccccccc} 
Variable & $\mathrm{N}$ & Sample & \multicolumn{5}{c}{ Percentiles } \\
& & & $\min$ & 25 & 50 & 75 & $\max$ \\
nROBA & 12 & Cluster 1 & -2.35 & 3.72 & 7.37 & 10.57 & 13.47 \\
& 8 & Cluster 2 & -7.65 & .12 & 2.75 & 4.49 & 13.93 \\
gROBA & 12 & Cluster 1 & .25 & 7.43 & 11.09 & 13.61 & 16.90 \\
& 8 & Cluster 2 & -5.11 & 2.89 & 5.56 & 6.99 & 15.81 \\
nPM & 12 & Cluster 1 & -2.02 & 1.67 & 2.88 & 5.24 & 6.79 \\
& 8 & Cluster 2 & -4.55 & .07 & 1.50 & 2.16 & 5.97 \\
gPM & 12 & Cluster 1 & -.80 & 3.08 & 4.57 & 6.67 & 8.78 \\
& 8 & Cluster 2 & -3.10 & 1.37 & 2.93 & 3.37 & 6.77
\end{tabular}

\subsection{Firm effect versus industry segment effect}

The second part of the research question "Do corporate level decisions differ across firms, and, if so, does it matter?" is concerned with the relative importance of the intra-industry corporate 
effect. To tackle this issue, the total variance in firm performance has to be decomposed into the sources of variation that can be identified: intra-industry effect, firm effects, and year effects. The results show that firm effects explain most of the variance in four performance variables (see Table 9). That has a bearing upon the importance of each firm having its own specific, singular resources and competences. The explanatory power of firm effects varies by about 30 to 40 percent while the intra-industry effect explains around 10 percent of the variance. Even though firm effects are dominant, intra-industry effects explain a significant portion of the variance in firm level performance. The firm effect is smaller than in previous studies using fixed effects or random effects models. It seems that these studies - due to an incorrect specification of the model - overestimate the firm effect. The results presented here are in line with the other two studies using multilevel analysis (see Table 11). The firm effect varies across the performance measures: firm effects are higher for returns on assets than for profit margins. The industry segment effect (or intra-industry effect) is more independent of the performance variable used.

Table 9: industry segment effect versus firm effect

\begin{tabular}{|c|l|l|l|l|}
\hline Unconditional model (intercept only) & nROBA & gROBA & nPM & gPM \\
\hline Level 1 variance $\left(\right.$ across time) $\left(\sigma_{\mathrm{e}}^{2}\right)$ & 24.042 & 26.605 & 6.668 & 7.181 \\
\hline Level 2 variance (between firms) $\left(\sigma_{\mathrm{e}}^{2}\right)$ & 18.741 & 18.141 & 3.39 & 3.288 \\
\hline Total variance & 42.783 & 44.746 & 10.058 & 10.469 \\
\hline Model incorporating year effects & & & & \\
\hline Level 1 variance $\left(\right.$ across time) $\left(\sigma_{\mathrm{e}}^{2}\right)$ & 24.844 & 27.289 & 6.82 & 7.291 \\
\hline Level 2 variance (between firms) $\left(\sigma_{\mathrm{e}}^{2}\right)$ & 17.315 & 16.926 & 3.146 & 3.084 \\
\hline Total variance & 42.159 & 44.215 & 9.966 & 10.375 \\
\hline Model with year and segment effects & & & & \\
\hline Level 1 variance (across time) $\left(\sigma_{\mathrm{e}}^{2}\right)$ & 20.649 & 21.537 & 5.91 & 6.139 \\
\hline Level 2 variance (between firms) $\left(\sigma_{\mathrm{e}}^{2}\right)$ & 17.288 & 16.898 & 3.144 & 3.082 \\
\hline Total variance & 37.937 & 38.435 & 9.054 & 9.221 \\
\hline
\end{tabular}

\begin{tabular}{|l|l|l|l|l|}
\hline Unconditional model (intercept only) & nROBA & gROBA & nPM & gPM \\
\hline \% of total variance across time & $56.2 \%$ & $59.5 \%$ & $66.3 \%$ & $68.6 \%$ \\
\hline \% of total variance between firms & $43.8 \%$ & $40.5 \%$ & $33.7 \%$ & $31.4 \%$ \\
\hline Model incorporating year effects & & & & \\
\hline \% of total variance across time & $58.1 \%$ & $61.0 \%$ & $67.8 \%$ & $69.6 \%$ \\
\hline \% of total variance between firms & $40.5 \%$ & $37.8 \%$ & $31.3 \%$ & $29.5 \%$ \\
\hline \% of total variance explained by year effects & $1.5 \%$ & $1.2 \%$ & $0.9 \%$ & $0.9 \%$ \\
\hline Model with year and segment effects & & & & \\
\hline \% of total variance across time (error) & $48.3 \%$ & $48.1 \%$ & $58.8 \%$ & $58.6 \%$ \\
\hline \% of total variance between firms (firm effect) & $40.4 \%$ & $37.8 \%$ & $31.3 \%$ & $29.4 \%$ \\
\hline$\%$ of total variance explained by year effects & $1.5 \%$ & $1.2 \%$ & $0.9 \%$ & $0.9 \%$ \\
\hline$\%$ of total variance explained by segment effects & $9.9 \%$ & $12.9 \%$ & $9.1 \%$ & $11.0 \%$ \\
\hline
\end{tabular}


Table 11: Research results compared

\begin{tabular}{|l|c|c|c|}
\cline { 2 - 4 } \multicolumn{1}{c|}{} & $\begin{array}{l}\text { Misangyi, V., Helms, } \\
\text { H., Greckhamer, T. \& } \\
\text { Lepine, J. (2006) }\end{array}$ & Hough, J. (2006) & $\begin{array}{l}\text { Houthoofd \& } \\
\text { Hendrickx } \\
\text { (nROBA) }\end{array}$ \\
\hline Effect & \% Var. explained & \% Var. explained & \% Var. explained \\
\hline Year effect & 0.8 & 5.3 & 1.5 \\
\hline Industry & 7.6 & & 9.9 \\
\hline Industry segment & & 20.2 & 40.4 \\
\hline Strategic group & 7.2 & 40.1 & 48.3 \\
\hline Corporate & 36.6 & 34.5 & \\
\hline Firm effect & & & \\
\hline Error & & & \\
\hline
\end{tabular}

A fixed effects model was also used in order to be able to compare the results (Houthoofd, Desmidt \& Gonzalez, 2010). A fixed effects sequential analysis of variance includes the year effects first, then the intra-industry segment effects, and finally the firm effects. Table 12 reports the results of a fixed effects model. The increment of $\mathrm{R}^{2}$ (with respect to the previous model in which the industry segments are included) reports the firm effects. The F-statistic shows the statistical significance of the different effects. Corroborating the findings of the fixed effects research with the present ML-results, it is obvious that the firm effects, according to the fixed effects model, are substantially higher. The explanatory power of firm effects varies from 55 percent in explaining nROBA and gROBA to 63 percent when explaining nPM and gPM. Intraindustry effects explain from 6.8 to 9.7 percent of the variance in the performance variables. The analysis also shows that all intra-industry segment effects and firm effects are statistically significant at conventional levels. Year effects, however, explain only about 2 percent of the variance and are not statistically significant at conventional levels. 
Table 12: industry segment effect versus firm effect with fixed effects model

\begin{tabular}{|c|c|c|c|c|c|}
\hline & \multicolumn{5}{|c|}{ nROBA } \\
\hline & $D F$ & $R^{2}$ & $\Delta R^{2}$ & $F$-test & Ser. Corr. \\
\hline YEAR & 5 & 0.024 & - & 0.52 & 0.83 \\
\hline INDUSTRY SEGMENT & 1 & 0.072 & - & $8.52 * * *$ & 0.78 \\
\hline FIRM & 19 & 0.621 & 0.549 & $7.93 * * *$ & 0.24 \\
\hline $\begin{array}{l}\text { GLOBAL MODEL } \\
\text { (FIRM+SEGMENT+YEAR) }\end{array}$ & 24 & 0.650 & & $6.72 * * *$ & 0.25 \\
\hline ERROR & 87 & 0.350 & & & \\
\hline \multirow[t]{3}{*}{ TOTAL } & 111 & & & & \\
\hline & \multicolumn{5}{|c|}{ gROBA } \\
\hline & $D F$ & $R^{2}$ & $\Delta R^{2}$ & $F$-test & Ser. Corr. \\
\hline YEAR & 5 & 0.020 & - & 0.44 & 0.83 \\
\hline INDUSTRY SEGMENT & 1 & 0.097 & - & $11.77 * * *$ & 0.78 \\
\hline FIRM & 19 & 0.646 & 0.549 & $8.84 * * *$ & 0.22 \\
\hline $\begin{array}{l}\text { GLOBAL MODEL } \\
\text { (FIRM+SEGMENT+YEAR) }\end{array}$ & 24 & 0.670 & & $7.35^{* * *}$ & 0.23 \\
\hline ERROR & 87 & 0.330 & & & \\
\hline \multirow[t]{3}{*}{ TOTAL } & 111 & & & & \\
\hline & \multicolumn{5}{|c|}{ nPM } \\
\hline & $D F$ & $R^{2}$ & $\Delta R^{2}$ & F-test & Ser. Corr. \\
\hline YEAR & 5 & 0.020 & - & 0.40 & 0.81 \\
\hline INDUSTRY SEGMENT & 1 & 0.068 & - & $8.02 * * *$ & 0.76 \\
\hline FIRM & 19 & 0.696 & 0.628 & $11.09 * * *$ & 0.03 \\
\hline $\begin{array}{l}\text { GLOBAL MODEL } \\
\text { (FIRM+SEGMENT+YEAR) }\end{array}$ & 24 & 0.718 & & $9.22 * * *$ & 0.05 \\
\hline ERROR & 87 & 0.282 & & & \\
\hline \multirow[t]{3}{*}{ TOTAL } & 111 & & & & \\
\hline & \multicolumn{5}{|c|}{ gPM } \\
\hline & $D F$ & $R^{2}$ & $\Delta R^{2}$ & $F$-test & Ser. Corr. \\
\hline YEAR & 5 & 0.016 & - & 0.34 & 0.81 \\
\hline INDUSTRY SEGMENT & 1 & 0.087 & - & $10.26 * * *$ & 0.76 \\
\hline FIRM & 19 & 0.722 & 0.635 & $12.27 * * *$ & 0.01 \\
\hline $\begin{array}{l}\text { GLOBAL MODEL } \\
\text { (FIRM+SEGMENT+YEAR) }\end{array}$ & 24 & 0.739 & & $10.02 * * *$ & 0.04 \\
\hline ERROR & 85 & 0.261 & & & \\
\hline TOTAL & 109 & & & & \\
\hline
\end{tabular}

\section{Discussion and conclusions}

The choice of segment within a single industry does matter. The median of net profit margin in the first industry segment is 1.3 percentage points higher, gross profit margin is 1.6 percentage points higher, net ROBA is 3.6 percentage points higher and gross ROBA is 5,5 percentage points higher relative to the second domain. Industry segments are defined by classifying firms in a 
strategic space, which can be thought of as a three-dimensional graph composed of three strategy dimensions (buyer groups, product types, geographical reach). An industry segment includes firms within an industry that define their competitive arena using these three dimensions in a similar way. Industry segment membership explains about 10 percent of the variation in performance between firms within an industry. This finding should urge managers to carefully (re)consider where (and how) they are competing within the industry, i.e. what business segment they want to be in.

By explicitly considering the industry segment targeted, firms may improve their competitor analysis and streamline competitor intelligence. Furthermore, significant threats and opportunities will be detected on a timelier basis, and a more solid basis for formulating the appropriate short-term tactics and long-term strategy will be provided (Sidhu, 2004). Determination of market boundaries is also a necessary prerequisite for determining a firm's market share (Curran and Goodfellow, 1989). Industry segments can affect the perception of strategic choices or options, and ultimately the bottom line of performance.

Moving from one segment to another can be difficult depending on the height of the mobility barriers needed to surmount. These mobility barriers, within the electrical wholesale sector, are product knowledge, trust from buyers, customer loyalty, loyalty to suppliers, specialized knowledge of the needs of buyers, specialized knowledge about products, etc. These resources are all difficult to imitate or to substitute and are highly valuable. Porter's five forces model is useful for explaining performance differences between intra-industry domains. A further analysis of seller power reveals that seller power differs statistically significantly between segments (research results not reported in this paper). Higher profitability occurs in wholesaling firms with fewer suppliers and tight relations with their two largest suppliers.

The firm effect is about 30 to 40 percent, reflecting the critical importance of the particular resources and capabilities of each firm. The resource-based view and its successors or refinements - CBV and DCV - highlight the strategic importance of rare, valuable, non-imitable, non-substitutable resources. Differences in competences will have their counterpart in differences in competitive strategy between firms, even within the same business domain. The firm effect in the study at hand is lower than in previous studies, due to the fact that most of the earlier studies do not consider intra-industry positions. By so doing the firm effect is overstated as it incorporates and absorbs the effect of the tough strategic choices concerning scale and scope (defining the business the firm is in).

But unexplained variance is about 50 to 60 percent, pointing to the fact that more research on this topic is necessary. Introducing specific competitive strategy decisions is a possible route forward. This may reduce the amount of unexplained variance, but such research can also disentangle the firm effect in a competitive strategy effect, which is due to differences in individual or lower level resources (e.g. the number of patents), and a higher level "firm effect" due to the use of bundles of resources, and thereby competences, in order to achieve the firm's objectives. 
Nevertheless, readers should interpret the results cautiously. This study relates to one industry and therefore the empirical findings need confirmation in other industries. The sample size is limited to 20 firms, although the study covers more than 95 percent of the industry. While small samples are not unusual in strategic management research, studies of large industries would provide a valuable additional perspective. 


\section{References}

Adner R, Helfat C. (2003) Corporate effects and dynamic managerial capabilities. Strategic Management Journal , 24:1011-1025

Arend RJ. (2009) Industry effects and firm effects: no effect is an island. Journal of Business Research ; 62:651-659.

Bain JS. (1951) Relation of profit rate to industry concentration: American manufacturing 193640. Quarterly Journal of Economics ; 65:293-324.

Bain JS. (1956) Barriers to new competition. Cambridge, MA: Cambridge University Press

Barney, J. (1991) Firm resources and sustained competitive advantage. Journal of Management, 17(1), 99-120.

Barney, J. (2002) Gaining and sustaining competitive advantage (2nd ed), Prentice Hall, Englewood Cliffs.

Bowman E, Helfat C. (2001) Does corporate strategy matter? Strategic Management Journal; 22:1-23

Brush TH, Bromiley P. (1997) What does a small corporate effect mean? A variance components simulation of corporate and business effects. Strategic Management Journal; 18:825-835.

Brush TH, Bromiley P, Hendrickx M. (1999) The relative influence of industry and corporation on business segment performance: an alternative estimate. Strategic Management Journal; 20:519-547.

Chen Y, Lin F. (2006) Sources of superior performance: industry versus firm effects among firms in Taiwan. European Planning Studies ; 14(6):733-751

Cool K, Schendel D. (1987) Strategic group formation and performance: the case of the US pharmaceutical industry, 1963 - 1982. Management Science ; 33:1102-1124.

Cool K, Schendel D. (1988) Performance differences among strategic group members. Strategic Management Journal ; 9:207-223.

Curran J, Goodfellow J. (1989) Theoretical issues in the determination of market boundaries. European Journal of Marketing ; 24:16-28.

Eriksen B, Knudsen T. (2003) Industry and firm level interaction: implication for profitability. Journal of Business Research ; 56:191-199

Everitt B. (1974) Cluster analysis. London: Heinemann Educational Books

Frazier GL, Howell RD. (1983) Business definition and performance. Journal of Marketing; 47(Spring):59-67.

Galbreath J, Galvin P. (2008) Firm factors, industry structure and performance variation: new empirical evidence to a classic debate. Journal of Business Research ; 61:109-117

Goddard J, Tavakoli M, Wilson J. (2009) Sources of variation in firm profitability and growth. Journal of Business Research ; 62:495-508

González E, Ventura J. (2002) How much do strategic groups matter. Review of Industrial Organization ; 21(1):55-71.

Hall, R. (1994) A framework for identifying the intangible sources of sustainable competitive advantage. Publ in Hamel \& Heene (1994) 
Hamel, G. and A. Heene (1994). Competence-Based Competition. Chichester, West Sussex, England, John Wiley \& Sons Ltd.

Hansen GS, Wernerfelt B. (1989) Determinants of firm performance: the relative importance of economic and organizational factors. Strategic Management Journal , 10:399-411.

Hawawini G, Subramanian V, Verdin P. (2003) Is performance driven by industry- or firmspecific factors? A new look at the evidence. Strategic Management Journal , 24:1-16

Hough, J.R. (2006) Business segment performance redux: a multilevel approach. Strategic Management Journal ; 27:45-51

Houthoofd, N., Desmidt, S. \& Gonzalez, E. (2009) Analyzing firm performance heterogeneity: the relative effect of business definition. Working Paper UGent, April, nr. 580, $31 \mathrm{p}$.

Houthoofd, N. Desmidt, S. \& González Fidalgo, E. (2010) Analyzing firm performance heterogeneity: the relative effect of business domain. Management Decision, Vol. 48, No. 6, pp. 996-1009

Houthoofd, N. (2011) Strategisch management: de strijd om voorsprong. Academia Press, Gent, 3rd edition.

Hunt, S. (2000) A general theory of competition. Sage Publications, Thousand Oaks.

Kessides I. (1990) Internal versus external market conditions and firm profitability: an exploratory model. The Economic Journal, 100(September):773-792.

Martens R. (1989) De strategische groepstheorie. Een toepassing op de Europese farmaceutische markt, 1978-1985. Economisch \& Sociaal Tijdschrift 3:251-270.

Martens R. (1988) Strategic group formation and performance implications. The case of the pharmaceutical industry in five E.C.- countries, 1978-1985. Antwerp: Unpublished Doctoral Dissertation, UFSIA

Mason ES. (1939) Price and production policies of large-scale enterprise. American Economic Review ; 29:61-74.

Mauri A, Michaels M. (1998) Firm and industry effects within strategic management: an empirical examination. Strategic Management Journal ; 19:211-219

McGahan A. (1999) The performance of US corporations: 1981-1994. The Journal of Industrial Economics; December:373-398.

McGahan A, Porter M. How much does industry matter, really? Strategic Management Journal 1997; 18(Summer Special Issue):15-30.

McGahan A, Porter M. (2005) Comment on 'Industry, corporate and business-segment effects and business performance: a non-parametric approach. Strategic Management Journal; 26(9):873-880.

McGee J, Segal-Horn S. (1990) Strategic space and industry dynamics: the implications for international marketing strategy. Journal of Marketing Management ; 6(4):175-193.

McNamara G, Aime F, Vaaler P. (2005) Is performance driven by industry- or firm-specific factors? A response to Hawawini, Subramanian, and Verdin. Strategic Management Journal, 26:1075-1081. 
Misangyi V, Helms H, Greckhamer T, Lepine J. (2006) A new perspective on a fundamental debate: a multilevel approach to industry, corporate, and business unit effects. Strategic Management Journal ; 27:571-590.

Porter ME. (1986) Changing patterns of international competition. California Management Review ; 2(Winter):9-40.

Powell T. (1996) How much does industry matter? An alternative empirical test. Strategic Management Journal ; 17(4):323-334.

Roquebert J, Phillips R, Westfall P. (1996) Markets vs. management: what 'drives' profitability? Strategic Management Journal ; 17:653-664

Ruefli T, Wiggins R. (2003) Industry, corporate, and segment effects and business performance: a non-parametric approach. Strategic Management Journal ; 24:861-879.

Rumelt RP. (1982) Diversification Strategy and Profitability. Strategic Management Journal ; 3:359-369.

Rumelt RP. (1991) How much does industry matter? Strategic Management Journal ; 12:167-185.

Sanchez, R. \& Heene, A. (1997) Reinventing strategic management: new theory and practice for competence-based competition. European Management Journal, Vol. 15, Nà. 3, June, pp. 303-317

Sanchez, R. (1997) Strategic management at the point of inflection: systems, complexity and competence theory. Long Range Planning, Vol. 30, pp. 939-946.

Scherer F. (1980) Industrial market structure and economic performance. Chicago, Rand-McNally

Schmalensee R. (1985) Do markets differ much? American Economic Review ; 75(3):341-351.

Sidhu J. (2004) Business-domain definition and performance: an empirical study," SAM Advanced Management Journal; Autumn: 40-45.

Short J, Ketchen D, Palmer T, Hult T. (2007) Firm, strategic group, and industry influences on performance. Strategic Management Journal, 28:147-167.

Short J, McKelvie A, Ketchen D, Chandler G. (2009) Firm and industry effects on firm performance: a generalization and extension for new ventures. Strategic Entrepreneurship Journal ; 3:47-65

Teece, D. (2007) Explicating dynamic capabilities: the nature and microfoundations of (sustainable) enterprise performance. Strategic Management Journal, 28, pp. 13191350.

Teece, D.J. (2010) Technological innovation and the theory of the firm: the role of enterpriselevel knowledge, complementarities, and (dynamic) capabilities. Publ. in Handbook of economics. Vol. 1, Elsevier

Wernerfelt B, Montgomery C. (1988) Tobin's q and the importance of focus in firm performance. American Economic Review ; March:246-250

$\mathrm{Wu}$, L-Y. (2010) Applicability of the resource-based and dynamic capability views under environmental volatility. Journal of Business Research, 63, pp. 27-31

Zeithaml CP, Fry LW. (1984) Contextual and strategic differences among mature businesses in four dynamic performance situations. Academy of Management Journal ; 27:841-860. 
Appendix: summary table with review of the literature

\begin{tabular}{|c|c|c|c|c|c|c|c|c|}
\hline & sample & $\begin{array}{l}\text { dependent } \\
\text { variable(s) }\end{array}$ & year & industry & group & $\begin{array}{l}\text { corpo- } \\
\text { ration }\end{array}$ & $\begin{array}{l}\text { business } \\
\text { unit } \\
\text { (firm) }\end{array}$ & error \\
\hline Schmalense 1985 & full sample & & & 19.5 & & & 0.6 & 79.9 \\
\hline $\begin{array}{l}\text { Wernerfelt \& } \\
\text { Montgomery } 1988\end{array}$ & $\begin{array}{l}\text { sample without correction for } \\
\text { intangible assets }\end{array}$ & Tobin's q & & 19.48 & & 2.61 & .94 & \\
\hline $\begin{array}{l}\text { Hansen \& Wernerfelt } \\
1989\end{array}$ & $\begin{array}{l}60 \text { large firms with over } 300 \\
\text { lines of businesses }\end{array}$ & ROA & & 18.5 & & & 37.78 & \\
\hline Kessides 1990 & $\begin{array}{l}1775 \text { observations, } 456 \text { firms, } \\
242 \text { manufacturing industries }\end{array}$ & return on sales & & 20.1 & & 9.8 & 27.5 & \\
\hline Rumelt 1991 & sample B & & & 4.03 & & 1.64 & 44.17 & 44.79 \\
\hline Roquebert et al. 1996 & $\begin{array}{l}\text { 1985-91; manufacturing; } \\
\text { Compustat; } 16596 \\
\text { observations }\end{array}$ & & & 10.2 & & 17.9 & 37.1 & 32.0 \\
\hline Powell 1996 & 54 responses from 166 surveys & \multicolumn{2}{|l|}{$\begin{array}{l}\text { perceived overall } \\
\text { performance }\end{array}$} & 15 & & & & \\
\hline & & \multicolumn{2}{|l|}{ perceived profitability } & 10 & & & & \\
\hline & & \multicolumn{2}{|l|}{ perceived sales growth } & 19 & & & & \\
\hline $\begin{array}{l}\text { McGahan \& Porter } \\
1997\end{array}$ & full sample & & 2.39 & 18.68 & & 4.33 & 31.71 & 48.4 \\
\hline \multirow[t]{3}{*}{$\begin{array}{l}\text { Mauri \&Michaels } \\
1998\end{array}$} & $1988-92$ & $\mathrm{R} \& \mathrm{D}$ intensity & & 62.2 & & & 30.8 & 7.0 \\
\hline & $1978-92$ & R\&D intensity & & 55.4 & & & 30.1 & 14.5 \\
\hline & 1988-92 & \multicolumn{2}{|l|}{ Advertising intensity } & 69.3 & & & 24.8 & 5.9 \\
\hline
\end{tabular}




\begin{tabular}{|c|c|c|c|c|c|c|c|c|}
\hline & sample & $\begin{array}{l}\text { dependent } \\
\text { variable(s) }\end{array}$ & year & industry & group & $\begin{array}{l}\text { corpo- } \\
\text { ration }\end{array}$ & $\begin{array}{c}\text { business } \\
\text { unit } \\
\text { (firm) }\end{array}$ & error \\
\hline & $1978-92$ & \multicolumn{2}{|l|}{ Advertising intensity } & 68.2 & & & 24.1 & 7.7 \\
\hline & $1988-92$ & ROA & & 6.2 & & & 36.9 & 56.9 \\
\hline & $1978-92$ & ROA & & 5.8 & & & 25.4 & 68.8 \\
\hline $\begin{array}{l}\text { Brush, Bromily \& } \\
\text { Hendrickx } 1999\end{array}$ & $\begin{array}{l}535 \text { firms, } 1605 \text { business } \\
\text { segments, all industries except } \\
\text { finance }\end{array}$ & ROA & & $\begin{array}{l}9.67- \\
15.32\end{array}$ & & & & \\
\hline \multirow[t]{3}{*}{ McGahan1999 } & \multirow[t]{3}{*}{$\begin{array}{l}\text { 1981-1994, } 31601 \\
\text { observations, } 4997 \text { firms, } 648 \\
\text { industries }\end{array}$} & Tobin's q & 3,1 & 41.5 & & & 55.2 & \\
\hline & & Accounting profit & 4,7 & 29.6 & & & 65.7 & \\
\hline & & $\begin{array}{l}\text { Return on } \\
\text { Replacement Sales }\end{array}$ & 7,4 & 31.6 & & & 60.9 & \\
\hline $\begin{array}{l}\text { Gonzalez \& Ventura } \\
2002\end{array}$ & $\begin{array}{l}\text { Spanish manufacturing firms, } \\
2059,1977,1869 \text { and } 1877 \\
\text { firms in 1991-92-93-94 } \\
\text { respectively }\end{array}$ & ROA & 0.8 & 10.4 & 11.5 & & 38.0 & 38.5 \\
\hline \multirow[t]{3}{*}{ Hawawini et al. 2003} & \multirow[t]{3}{*}{$\begin{array}{l}\text { data provided by the } \\
\text { consultancy Stern Stewart, } \\
\text { Compustat }\end{array}$} & $\mathrm{EP} / \mathrm{CE}$ & 1.9 & 6.5 & & & 27.1 & 60.3 \\
\hline & & TMV/CE & 1.3 & 11.4 & & & 32.5 & 51.9 \\
\hline & & $\mathrm{ROA}$ & 1.0 & 8.1 & & & 35.8 & 52.0 \\
\hline Adner \& Helfat 2003 & US petroleum industry, 1977- & ROA & 1.26 & 2.05 & & 2.74 & 19.42 & 63.86 \\
\hline
\end{tabular}




\begin{tabular}{|c|c|c|c|c|c|c|c|c|}
\hline & sample & $\begin{array}{l}\text { dependent } \\
\text { variable(s) }\end{array}$ & year & industry & group & $\begin{array}{l}\text { corpo- } \\
\text { ration }\end{array}$ & $\begin{array}{c}\text { business } \\
\text { unit } \\
\text { (firm) }\end{array}$ & error \\
\hline $\begin{array}{l}\text { Ruefli \& Wiggins } \\
2003\end{array}$ & full sample & ROA & 0.01 & 0.14 & & 7.06 & 12.33 & \\
\hline $\begin{array}{l}\text { Eriksen \& Knudsen } \\
2003\end{array}$ & Danish SME's, 1991-1995 & ROA & & 11 & & & 81 & \\
\hline \multirow[t]{2}{*}{ Misangyi et al. 2006} & full sample (HLM-method) & $\mathrm{ROA}$ & 0.8 & 7.6 & & 7.2 & 36.6 & 47.8 \\
\hline & $\begin{array}{l}\text { full sample (square roots of the } \\
\text { estimated variances) }\end{array}$ & ROA & 4.6 & 14.3 & & 13.9 & 31.3 & 35.8 \\
\hline Hough 2006 & 19405 firms (1995-99) & $\mathrm{ROA}$ & $<1.0$ & 5.3 & & 20.2 & 40.1 & 34.5 \\
\hline Short, et al. 2007 & 1165 firms, 12 industries & $\mathrm{ROA}$ & & 16.9 & 11.3 & & & \\
\hline \multirow[t]{3}{*}{ Short et al. 2009} & \multirow[t]{3}{*}{ new venture sample } & sales & & 14.59 & & & 41.31 & 44.1 \\
\hline & & survival & & 1.36 & & & 98.33 & \\
\hline & & sales growth & 5.51 & 14.02 & & & 52.28 & 28.19 \\
\hline \multirow[t]{3}{*}{ Short et al. 2009} & \multirow[t]{3}{*}{ established firms } & sales & & 21.76 & & & 63.22 & 15.02 \\
\hline & & survival & & 1.16 & & & 98.84 & \\
\hline & & sales growth & 2.65 & 23.57 & & & 64.35 & 9.52 \\
\hline Arend 2009 & $1998-2000$ & $\mathrm{ROA}$ & & 9.56 & & & 90.44 & \\
\hline Goddard et al. 2009 & 1996-2000, sample A, & profit rate & & 2.92 & & & 32.15 & \\
\hline
\end{tabular}




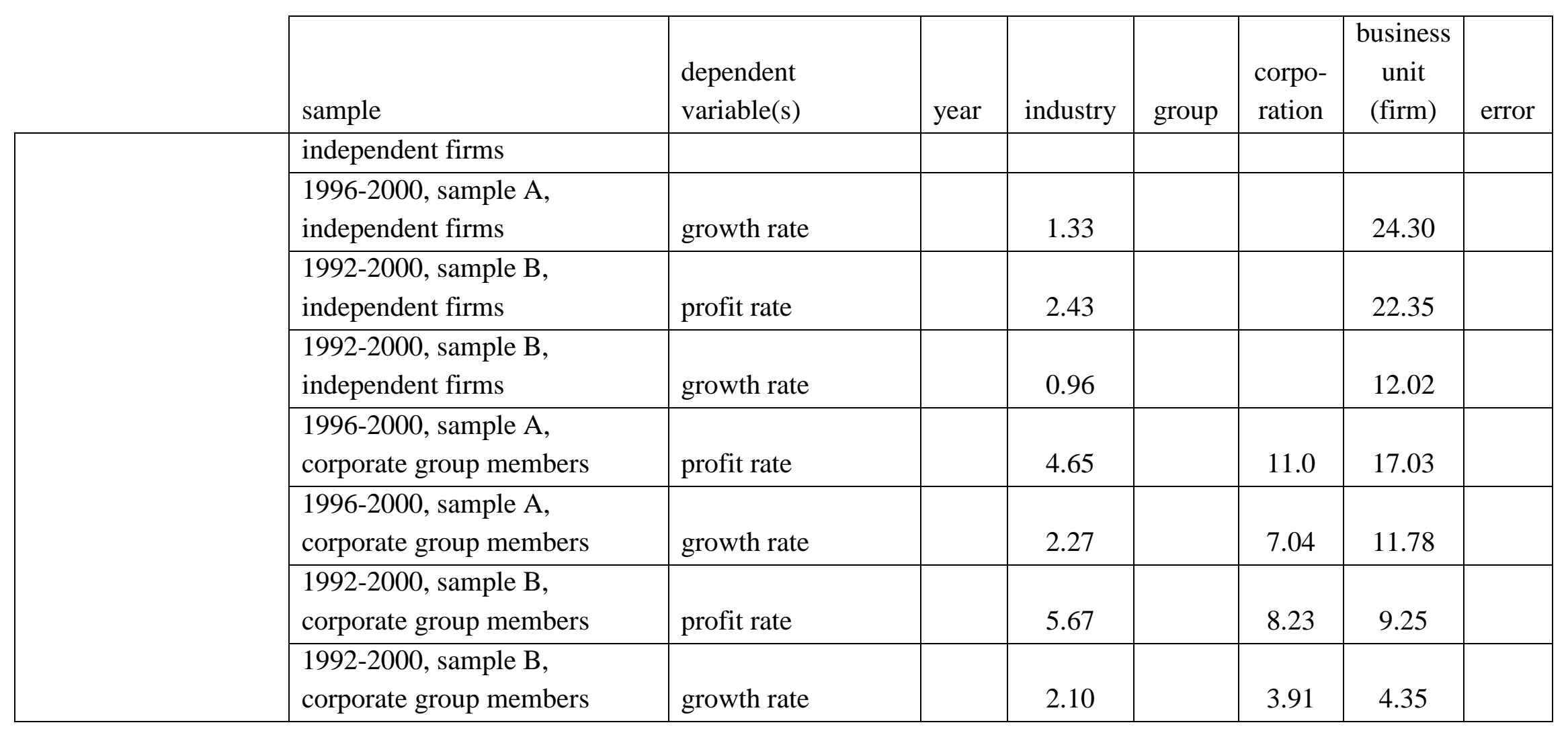


